\title{
MANAJEMEN KOMUNIKASI DALAM PERWUJUDAN TANGGUNG JAWAB SOSIAL PERUSAHAAN PT JASA MARGA (PERSERO) TBK MELALUI PROGRAM BINAAN BANKSASUCI
}

\author{
Dwi Kartikawati ${ }^{1}$, Rahmawati Puspitasari ${ }^{2}$ \\ 1,2 Universitas Nasional Jakarta
}

Naskah diterima tanggal 02-04-2020, direvisi tanggal 12-06-2020, disetujui tanggal 04-07-2020

\begin{abstract}
Abstrak. Fokus riset ini adalah untuk mengetahui manajemen komunikasi sebagai perwujudan Tanggung Jawab Sosial Perusahaan PT Jasa Marga melalui Program Binaan Banksasuci. Program Banksasuci merupakan program bina lingkungan PT Jasa Marga yang bertujuan untuk mengelola sungai secara terintegrasi, yaitu dengan memelopori penanaman pohon untuk mengurangi polusi, mengelola keberagaman hayati yang berada di bantaran sungai, dan mengelola sampah yang didapat dari sungai Cisadane. Manajemen komunikasi yang baik sangat dibutuhkan demi tercapainya tujuan dengan melalui tahapan perencanaan, pelaksanaan dan pengevaluasian kegiatan komunikasi dalam program yang dilakukan. Dengan menggunakan penelitian kualitatif analitik dan teknik pengumpulan data dengan wawancara mendalam, studi observasi dan studi dokumen. Maka hasil penelitian menunjukkan bahwa manajemen komunikasi dilakukan mulai dari tahapan perencanaan komunikasi pada program Banksasuci dimulai dengan persiapan, tahap pelaksanaan kegiatan komunikasi melalui penandatanganan perjanjian kerjasama dan penyerahan bantuan dan tahap evaluasi melalui evaluasi dan monitoring komunikasi melalui reminding call dan whatshapp grup. Keseluruhan kegiatan Program Tanggung Jawab Sosial Perusahaan PT Jasa Marga mendasarkan pada prinsip Triple Bottom Line yang selalu memperhatikan dari sisi keberlangsungan masyarakat, sisi lingkungan hidup dan sisi profit.
\end{abstract}

Kata kunci: Manajemen Komunikasi, Tanggung Jawab Sosial Perusahaan

Abstract.The focus of this research is how communication management as a form of PT Jasa Marga's Corporate Social Responsibility through the Banksasuci Development Program. This program is an environmental development program that aims to manage integrated rivers, namely pioneering tree planting to reduce pollution, managing biodiversity on the banks of the river, and managing waste from the Cisadane river. Good communication management is needed for the achievement of objectives through the stages of planning, implementing and evaluating communication activities. This research is a qualitative analytic research. Data collection techniques with in-depth interviews, observation studies and document studies. The results showed that the communication management stage was carried out starting from the communication planning at the Banksasuci program, the preparation phase, the implementation stage of communication through the signing of a cooperation agreement and the delivery of assistance and the evaluation and monitoring stage through reminding calls, whatshapp group. All activities of the company's PT Jasa Marga's corporate social responsibility program are based on the Triple Bottom Line principle, by paying attention to the sustainability of society, the environment and profit.

Keywords: Communication Management, Corporate Social Responsibility 


\section{PENDAHULUAN}

BUMN (Badan Usaha Milik Negara) berkewajiban menyisihkan 2 - 4\% dari laba bersih untuk Program Kemitraan dan Bina Lingkungan sebagai wujud dari kegiatan Tanggung Jawab Sosial Perusahaan (TJSP) atau yang disebut Corporate Social Responsibility (CSR). Kegiatan TJSP ini telah menjadi kewajiban legal yang diatur dalam Undang-Undang (UU) nomor 40 tahun 2007 tentang Perseroan Terbatas dan UU nomor 25 tahun 2007 tentang Penanaman Modal. Pengertian kegiatan TJSP adalah wujud komitmen bisnis untuk berkontribusi pada pembangunan ekonomi berkelanjutan, bekerja dengan karyawan, keluarga mereka, masyarakat lokal dan masyarakat luas untuk meningkatkan kualitas hidup mereka (Widjaja, G., \& Pratama, 2018). Program TJSP merupakan jembatan pertemuan antara kepentingan perusahaan dengan masyarakat di sekitar lingkungan perusahaan, kegiatan ini mempunyai peran yang sangat penting bagi masyarakat maupun bagi perusahaan. Karena dengan adanya tanggung jawab perusahaan maka dapat mendorong pemberdayaan masyarakat, dan sekaligus membantu perusahaan memperlancar operasional perusahaan (Mursitama, Noerlina, \& Wulandari, 2019)

Dalam pelaksanaan kegiatan TJSP, perusahaan harus mengutamakan kepentingan stakeholder yang dirangkum dalam tiga kepentingan yang disebut dengan prinsip dasar yaitu triple bottom lines atau dikenal juga dengan 3P (People, Planet, Profit). People pada sisi keberlangsungan masyarakat, planet pada sisi lingkungan hidup dan profit dari sisi keberlangsungan laba. Istilah Triple Bottom Line dipopulerkan pada tahun 1997 oleh Elkington melalui buku Cannibal With Forks: The Triple Bottom Lin in 21st Century Busines, dengan istilah economy properity, environmental quality dan social justice (Michael, Raharjo, \& Resnawaty, 2019).

PT Jasa Marga melalui bina lingkungan menyalurkan bantuan Program Banksasuci. Banksasuci atau singkatan dari Bank Sampah Sungai Cisadane adalah hasil binaan dari kegiatan TJSP PT Jasa Marga bertujuan untuk mengelola sungai secara terintegrasi, yaitu dengan memelopori penanaman pohon untuk mengurangi polusi, mengelola keanekaragaman hayati yang berada di bantaran sungai, dan mengelola sampah yang didapat dari sungai Cisadane. Sebagai salah satu sungai terpanjang di Provinsi Banten dengan panjang $126 \mathrm{~km}$, serta sebagai sumber kehidupan, sungai Cisadane harus dijaga kebersihannya baik dari sampah maupun dari limbah. Bank Sampah Sungai Cisadane (Banksasuci) berdiri sejak tahun 2012. Salah satu pengelola Banksasuci yaitu Ade Yunus tergerak hatinya untuk ikut terjun menjaga kelestarian sungai atas dasar semangat Penggiat Lingkungan yang memiliki kepedulian yang sama untuk turut serta merawat kebersihan sungai Cisadane. Banksasuci diharapkan bisa menjadi wadah bagi Penggiat Lingkungan di Kota Tangerang. Banksasuci diharapkan bukan hanya sekedar komunitas Peduli Sampah saja, jangka panjang diharapkan menjadi salah satu Destinasi Wisata Kota Tangerang, sebagai Taman Arboretrum dan pusat kajian Lingkungan Hidup di Kota Tangerang. Dengan kegiatan ini sebagai wujud komitmen menjaga binaan lingkungan sungai Cisadane, maka PT Jasa Marga pada tanggal 25 April 2018 mendapatkan penghargaan terkait lingkungan dalam gelaran "Indonesia green awards2018 (IGA 2018)" yaitu penghargaan yang diberikan oleh The La Tofi School Of CSR kepada perusahaan yang memiliki kepedulian tinggi terhadap lingkungan melalui berbagai ragam kreatifitas atau kepada siapa saja yang dianggap berprestasi dan berjasa bagi lingkungan sekitar.

Dengan demikian implementasi Program Banksasuci ini memerlukan manajemen komunikasi yang baik dalam mengoptimalkan sumber daya komunikasi yang ada untuk mencapai keefektifan program. Mengingat dengan manajemen komunikasi yang baik dalam upaya pelaksanaan kegiatan tanggung jawab perusahaan sangat dibutuhkan demi tercapainya tujuan dengan melalui tahapan perencanaan, pelaksanaan dan pengevaluasian kegiatan komunikasi dalam program yang dilakukan. Untuk bisa melaksanakan program TJSP dengan baik, perusahaan harus mampu memanfaatkan dan mengalokasikan sumber daya yang 
dimilikinya dengan baik, sehingga para stakeholder perusahaan bisa memperoleh manfaat atas pelaksanaan kegiatan tersebut.

Caranya adalah dengan manajemen (pengelolaan) komunikasi yang baik. Manajemen Komunikasi adalah cara individu atau manusia mengelola proses komunikasi melalui penyusunan kerangka makna dalam berbagai lingkup komunikasi. Proses tersebut meliputi perencanaan, pelaksanaan dan pengevaluasian kegiatan komunikasi untuk mencapai sasaran secara efektif dan efisien (Abidin, 2015) Pada intinya, hasil dari sebuah proses komunikasi adalah terciptanya dialog yang berjalan dua arah dan sekaligus melahirkan pertukaran informasi yang relatif seimbang.(Yusuf \& Ridwan, 2018) Maka riset ini penekanannya pada manajemen komunikasi sebagai wujud TJSP PT Jasa Marga melalui program Banksasuci dengan melihat pada perencanaan, pelaksaan dan pengevalusian kegiatan komunikasinya.

Pada penelurusan pada riset-riset terdahulu, dapat di telusuri pada penelitian Tahun 2013 dari Sitti Murniati Muhtar, Hafied Cangara, A. Alimuddin Unde, Universitas Hasanudin yang berjudul Strategi Komunikasi Dalam Pelaksanaan Program Corporate Social Responsibility (CSR) Oleh Humas PT Semen Tonasa Terhadap Komunitas Lokal di Kabupaten Pangkajene dan Kepulauan (Muhtar, Cangara, \& Unde, 2013). Pada riset ini kecenderungannya pada strategi komunikasi CSR nya, sedangkan pada penelitian ini, peneliti lebih ke arah pengelolaan komunikasinya, selain itu secara teoritis peneliti menggunakan prinsip teoritis Triple Bottom Line.

Penelitian lainnya adalah dari Rahma Yulaika Pada Tahun 2019 yang berjudul Strategi Pengelolaan Komunikasi Corporate Social Responsibility (CSR) PT Perkebunan Nusantara V Melalui Program Kemitraan Dalam Pemberdayaan UMKM Di Kabupaten Kampar. (Yulaika, 2019) Perbedaannya lebih pada jenis kegiatan TJSP BUMN dan secara temuan lebih pada pengelolaan program Kemitraan tersebut. Dengan demikian, riset ini bertujuan untuk mengetahui; Bagaimana manajemen komunikasi sebagai erwujudan Tanggung Jawab sosial perusahaan pada PT Jasa Marga melalui Program Binaan Banksasuci.

\section{METODE PENELITIAN}

Desain riset yang digunakan adalah desain riset kualitatif. Dalam riset ini tidak mengandalkan bukti berdasarkan logika sistematis, prinsip angka, atau metode statistik. Pembicaraan yang sebenarnya, isyarat, dan tindakan sosial lainnya adalah bahan mental untuk analisis kualitatif, meskipun penelitian kualitatif banyak bentuknya seiring menggunakan jumlah penghitung, penelitian tidak menggunakan nilai jumlah seperti yang digunakan dalam pengumpulan dan analisis data dalam eksperimen dan survei, metode kualitatif bisa kritis dan empiris (Mulyana, 2010: 150).

Metode kualitatif yang dilakukan dengan deskriptif melalui interaksi dengan orang-orang yang berhubungan dengan fokus penelitian untuk mendapatkan informasi yang diperlukan. Sedangkan teknik pengumpulan data dilakukan dengan wawancara mendalam, yang menyangkut partisipan yang tentunya sudah memiliki informasi yang dibutuhkan dan benarbenar terlibat kegiatan Tanggung Jawab Sosial Perusahaan (TJSP) ini. Pemilihan Key Informan dalam penelitian ini adalah Community Development Head yaitu TP yang bertanggung jawab dalam kegiatan TJSP PT Jasa Marga. Sedangkan Informan ke 1 dalam penelitian ini adalah planning and preparation head yaitu ES, yang merupakan bagian perencanaan dan persiapan dalam kegiatan. Keduanya mewakili pihak yang terkait dalam menjalankan kegiatan TJSP Jasa Marga serta informan ke 2 yaitu A, disamping itu peneliti juga melakukan wawancara dengan informan ke 3 yaitu AY selaku perwakilan masyarakat sekitar.

Peneliti juga melakukan observasi lapangan dan juga studi dokumen baik dokumen perusahaan, dokumen buku-buku, jurnal-jurnal dan lain-lain. Pada proses analisis data, data yang terkumpul dianalisis dengan teknik deskriptif-kualitatif. Pertama-tama keseluruhan data disajikan dalam display data, kemudian direduksi mana yang relevan dan mana yang tidak, dengan pokok permasalahan yang diteliti untuk kemudian dibuat kategorisasi. Tahap berikutnya adalah membuat interpretasi dan kesimpulan hasil penelitian (Lestari, Prabowo, \& 
Wibawa, 2012: 179).Validitas data dalam penelitian ini dilakukan dengan triangulasi sumber data (Suwarso, 2020:4). Peneliti menguji konsistensi data yang diperoleh melalui metode pengumpulan data yang beragam yaitu wawancara, observasi, dan dokumen untuk membantu membangun kredibilitas.

\section{HASIL PENELITIAN DAN PEMBAHASAN}

Dalam penelitian ini disajikan beberapa point penting dari kegiatan Tanggung Jawab Sosial Perusahaan (TJSP) PT Jasa Marga sebagai gambaran mengenai kegiatan yang dilakukan, kemudian penjelasan detil mengenai Program Banksasuci, kemudian membahas manajemen komunikasi pada TJSP yang terkait dengan Program Banksasuci.

\section{Kegiatan Tanggung Jawab Sosial Perusahaan (Corporate Social Responsibility) PT Jasa Marga}

Program Kegiatan TJSP merupakan bentuk pertanggung jawaban dunia usaha terhadap masyarakat dan lingkungan sebuah perusahaan atau badan usaha harus dilaksanakan dengan serius dan berkelanjutan. Pasalnya, bukan sekedar 'menggugurkan kewajiban'. Jasa Marga memiliki Program Kemitraan dan Program Bina Lingkungan (PKBL) yang dikelola oleh Unit Community development program (CDP). Kebijakan Unit CDP di lingkungan Perseroan dilakukan melalui wilayah operasi yang terdiri dari Kantor Pusat dan delapan kantor cabang. Salah satu langkah konkret unit ini adalah menyalurkan pinjaman usaha kepada Usaha Mikro Kecil Menengah (UMKM) secara tepat sasaran. Selain penyaluran pinjaman, Unit CDP juga bertanggung jawab melakukan monitoring untuk mengetahui perkembangan usaha mitra binaan. Unit CDP juga memberi bantuan pembinaan berupa pelatihan dan pemasaran, mulai dari membuat desain kemasan sampai melakukan pemasaran melalui online kepada para mitra binaan untuk membantu memajukan usaha para mitra binaan.

Selain itu kegiatan TJSP PT Jasa Marga dalam bina lingkungan yaitu penataan aliran sungai serta perbaikan ekosistem lingkungan sungai Cisadane. PT Jasa Marga (Persero) Tbk mengembangkan program bina lingkungan peningkatan peran masyarakat atau lembaga di sekitar bantaran sungai Cisadane Tangerang. Program Kegiatan TJSP juga merupakan kegiatan bantuan (hibah) untuk peningkatan kualitas hidup masyarakat pada daerah operasional PT Jasa Marga (Persero) Tbk. Program Bina Lingkungan digunakan untuk tujuan yang memberikan manfaat kepada masyarakat di wilayah operasional perseroan. Jenis bantuan yang diberikan PT Jasa Marga (Persero) Tbk. untuk komunitas Banksasuci yaitu program bina lingkungan untuk pengentasan kemiskinan dan pelestarian alam. Banksasuci adalah hasil binaan dari PT Jasa Marga (Persero) Tbk mengenai pelestarian alam.

\section{Program Binaan Banksasuci}

Bank Sampah Sungai Cisadane (Banksasuci) didirikan atas dasar semangat para penggiat lingkungan yang memiliki kepedulian yang sama untuk turut serta merawat kebersihan sungai Cisadane. Banksasuci adalah wilayah binaan Jasa Marga yang diarahkan untuk mengelola sungai secara terintegrasi, yaitu dengan memelopori penanaman pohon untuk mengurangi polusi, mengelola keberagaman hayati yang berada di bantaran sungai, dan mengelola sampah yang didapat dari Sungai Cisadane.

Sungai Cisadane adalah salah satu sungai terpanjang di Provinsi Banten yang berdiri sejak tahun 2012 silam, yang berada di Jl Taman Cisadane, Gang Muara Buntu, Kelurahan Panunggangan Barat, Kecamatan Cibodas, Kota Tangerang merupakan sumber kehidupan bagi masyarakat Tangerang dan sekitarnya, karena sungai Cisadane merupakan sumber air utama bagi masyarakat Tangerang. Sungai Cisadane harus dijaga kebersihannya baik dari sampah maupun dari limbah. Hal itu yang mendorong Ade Yunus selaku masyarakat sekitar Sungai Cisadane yang tergerak hatinya untuk ikut terjun menjaga kelestarian sungai sepanjang 
126 km. Banksasuci diharapkan bisa menjadi wadah bagi penggiat Lingkungan di Kota Tangerang.

Kegiatan rutin Banksasuci yang dilakukan masyarakat sekitar dalam pelestarian sungai Cisadane antara lain menjaring sampah dengan menggunakan rakit yang dibentangkan ke sungai, sampah yang terjaring diangkat dan dipilah, hasil pilahan sampah ada yang dicacah menggunakan mesin pencacah, ada yang dijadikan sebagai pupuk organik, ada juga yang didaur ulang. Selain menjaring sampah, kegiatan dari Banksasuci juga mengumpulkan sampah dari masyarakat yang berada di sekitar bantaran sungai Cisadane, kemudian dijual ke Banksasuci dengan sistem menabung. Hasil tabungannya dapat digunakan untuk biaya keperluan sekolah atau untuk kebutuhan rumah tangga lainnya. Tujuannya untuk mengurangi sampah dari sumber dan menghilangkan kebiasaan masyarakat yang suka membuang sampah kesungai. Selain itu ada juga kegiatan rutin yang dilakukan yaitu pembibitan dan penanaman pohon dibantaran sungai Cisadane untuk mencegah pengikisan sungai dan bisa menambah Ruang Terbuka Hijau (RTH) bagi kota Tangerang. Sedangkan untuk kegiatan rutin harian, Banksasuci melakukan patroli sungai Cisadane menggunakan empat perahu boat untuk monitoring pencemaran sungai, baik oleh limbah industri maupun oleh limbah domestik.

\title{
Manajemen Komunikasi sebagai wujud Kegiatan Tanggung Jawab Sosial Perusahaan
}

Berdasarkan analisis dari hasil wawancara kepada Key Informan dan Informan ke satu mengenai Manajemen Komunikasi pada kegiatan Tanggung Jawab Sosial Perusahaan PT Jasa Marga (Persero) Tbk. melalui program Banksasuci melalui beberapa tahapan. Pada tahapan perencanaan komunikasi di awali dengan tahap persiapan dengan melakukan komunikasi antar tim corporate communication dari PT Jasa Marga (Persero) Tbk. Mereka merupakan komunikator dari Pihak PT Jasa Marga. Seperti yang dikatakan Key Informan sebagai berikut:

\begin{abstract}
"Yang terlibat dalam pelaksanaan program CSR Banksasuci itu ada community development mba selain itu juga ada tim corporate communication, tapi yang pokok dalam melaksanakan kegiatan itu ya community development selaku tim perencanaan dan pelaksana, corporate communication itu selaku publikasi dan komunikasi. Selain itu ada 7 BUMN karya lainnya ada Hutama Karya, Nindya Karya, Adhi Karya, Wijaya Karya, Waskita, Abipraya, dan Pembangunan Perumahan mereka selaku pemodal pembangunan lainnya. Jadi yang bertugas ya community development selaku yang mengawali pembiayaan trus BUMNBUMN lain selaku pemodal untuk mewujudkan pengembangan tadi, pemerintah daerah juga selaku regulasi-regulasinya dan kementrian selaku yang menginisiasi untuk mengembangkan lebih luas lagi."
\end{abstract}

Pernyataan serupa juga dikatakan oleh informan ke 1, yang mengatakan bahwa yang terlibat dalam program Binaan Banksasuci itu ada pada divisi community development dan corporate secretary. Community development ialah yang melaksanakan kegiatan mulai dari perencanaan hingga pelaksanaan sedangkan corporate communication adalah yang bertugas mengkomunikasikan dan mempublikasikannya:

"Yang terlibat itu ya dari Jasa Marga itu sendiri ya mba terutama divisi community development dan corporate secretary. Community development ialah yang melaksanakan kegiatan mulai dari perencanaan hingga monitoring dan evaluasi sedangkan corporate communication adalah yang mengkomunikasikan dan mempublikasikannya trus juga ada 7 BUMN karya tadi yang disebutkan trus pemerintah setempat juga ikut berkontribusi dan yang paling utama kementrian." 
Pada tahap perencanaan komunikasi dalam kegiatan community development dilakukan melalui rapat internal, pada saat rapat internal tersebut tim PT Jasa Marga (Persero) Tbk yang akan melaporkan bagaimana respon masyarakat yang sudah dilaksanakan, melakukan survei lokasi, evaluasi dan penilaian hasil survei serta mencari jalan keluar dari kendala-kendala yang dihadapi selama melaksanakan program. Pada kegiatan survei juga dilakukan monitoring melalui komunikasi whatshapp. Lebih jauh informan ke 3 selaku perwakilan dari masyarakat sekitar mengatakan:"Yang bertugas ya kita semua ya tentunya, jadi Jasa Marga dan BUMNBUMN karya lainnya sebagai pemodal dan kita masyarakat yang tugasnya menjaga, merawat, dan mengalokasikan Banksasuci ini sebagai wadah yang bermanfaat untuk siapapun terutama untuk masyarakat sekitar."

Pada tahap pelaksanaan komunikasi menjadi kunci yang penting dalam kegiatan TJSP PT Jasa Marga (Persero) Tbk, antara lain melakukan komunikasi rutin dan dilakukan penandatanganan perjanjian kerjasama dan penyerahan bibit pohon secara simbolis berupa 50 bibit pohon seperti mangga, kedondong, jambu, pepaya, dan beberapa jenis bunga lainnya. Selain itu Jasa Marga juga memberikan perahu boat dan memberikan peralatan berupa piring dan lain-lain untuk kebutuhan mereka. Tujuh BUMN karya lainnya selaku pemodal memberikan bantuan untuk pembangunan fasilitas lain seperti Nindya Karya dan Abipraya membuat saung pertemuan, Wika membuat toilet umum, Hutama Karya membuat saung belajar, Waskita membuat wall climbing, dan Adhi Karya membuat flying fox. Komunikasi rutin juga terus dijalin, dilakukan guna mengawasi jalannya kegiatan mulai dari tahap perencanaan, pelaksanaan, hingga pemeliharaan, seperti yang dikatakan key informan:

"Komunikasi rutin itu pasti mba, nah komunikasi rutin yang kami lakukan itu ya dengan ngobrol-ngobrol sampai dimana proses pelaksanaan hingga pemeliharaan. Justru kita yang dikontrol oleh kementrian karena kita diberi tugas oleh kementerian untuk mengembangkan ini dan bagaimana realisasi dalam perencanaan itu kami dikontrol setiap 3 minggu sekali oleh kementrian."

Pernyataan tersebut di perkuat oleh informan ke 1 yaitu yang menyampaikan sarana komunikasi yang digunakan lebih bersifat informal dalam arti mereka tidak kita wajibkan untuk laporan tiap minggu tapi laporan mereka per kegiatan, seperti yang ia katakan:

"Komunikasi rutin yang digunakan selama ini yatu komunikasi informal dalam arti mereka tidak kita wajibkan untuk laporan tiap minggu tapi laporan mereka per kegiatan. Misalnya laporan kegiatan tentang saung pertemuan, saungnya sudah digunakan untuk masyarakat untuk kumpul, reuni, wedding juga kaya gitu sih mba paling komunikasi rutinnya. Selain itu juga kita komunikasi melalui by phone atau whatsApp bila tidak bertemu langsung."

Hal senada juga dikatakan oleh informan ke 2 yang mengatakan sarana komunikasi rutin dilakukan untuk mengetahui sampai dimana proses perkembangan program Banksasuci itu ada, dan biasa dikomunikasikan melalui WhatsApp group. Informan mengatakan: "Sarananya itu ada, gak mungkin ga ada ya mba, apalagi untuk komunikasi rutin ya kita selalu komunikasikan gimana perkembangan program sudah sejauh mana berjalan. Komunikasi rutin itu ya biasa kita komunikasikan melalui WhatsApp group kita apabila tidak bertemu langsung ya mba.."

Pada tahapan montoring dan evaluasi komunikasinya mengarah kepada monitoring kegiatan dan berupaya selalu mengkomunikasikan apabila ada masalah yang tidak berjalan sesuai yang dilaksanakan pada awal rencana kegiatan. Informan ke 1 menyatakan bahwa kegiatan berjalan sesuai dengan perencanaan awal dan belum ada hal-hal yang tidak sesuai dengan perencanaan, seperti penyataan berikut: "Untuk hal-hal seperti ini sampai sekarang Alhamdulillah masih sesuai dengan rencana awal ya mba jadi ya belum keluar jalur dan sampai kedepannya semoga sesuai dengan yang kita harapkan tentunya, intinya kalau ada permasalahan segera dikomunikasikan'. 
Selain itu dalam tahap akhir mewujudkan suatu program pasti akan selalu ada kritik dan saran dari setiap masyarakat yang diberikan suatu program, namun pada program Banksasuci ini tidak ada kritik dari masyarakat sampai saat ini tetapi justru masyarakat merasa berterima kasih atas bantuan yang sudah diberikan, seperti yang dikatakan key informan :"Kalau kritik dari masyarakat sampai saat ini belum ada, masyarakat malah merasa berterima kasih atas bantuan dari BUMN-BUMN karya yang sudah membantu lingkungan tersebut menjadi lebih tertata."

Lebih jauh informan 1 mengatakan: "Kalau sejauh ini sih belum, tapikan kedepannya kita juga tidak tahu dan kalaupun ada kritik dari masyarakat akan kita komunikasikan, kita bahas, dan dievaluasi sebaiknya harus seperti apa dan bagaimana. Tapi sih yang kita harapkan ya tidak ada kritik mba dari masyarakat karena program ini membantu mereka agar taraf hidupnya menjadi lebih baik."

\section{Implementasi Prinsip Triple Bottom Line}

Pengimplementasian prinsip Triple Bottom Line. Yang dimulai dari : People, dalam kegiatan TJSP pada program Banksasuci dilakukan dengan cara mengembangkan masyarakatnya. Hal ini menjadi inti kegiatan karena memiliki harapan memberi kemanfaatkan pada keberlansgungan masyarakat, contohnya anak-anak yang tidak mampu mendapat pendidikan usia dini dengan diadakannya PAUD. Selain itu masyarakatnya pun di bina untuk merawat apa yang sudah diberikan oleh Jasa Marga, seperti yang dikatakan Key informan:

"Dalam hal ini, masyarakat yang tadinya kurang mampu jadi mampu. Bukan hanya itu saja anak-anaknya juga mendapat pendidikan dengan diadakannya PAUD karena kan disana kita juga membuat sarana belajar yang dibangun oleh Hutama Karya untuk anak usia dini. Pengimplementasiannya itu ya dengan cara masyarakatnya kita bina untuk merawat bibit pohon yang sudah kita berikan lalu kalau sudah membuahkan hasil nanti dijual oleh masyarakat sekitar nah kan hasilnya bisa mereka manfaatkan untuk kebutuhan mereka sehari-hari."

Bantuan dari BUMN misalnya dari Hutama Karya berupa saung belajar untuk anakanak PAUD bisa memanfaatkan fasilitas yang sudah disediakan agar mereka bisa belajar dan mendapatkan kualitas pendidikan yang baik untuk kedepannya. Jadi terdapat sinergi baik dari Jasa Marga ataupun dari BUMN lain yang akhirnya menjadi memberi kemanfataan pada masyarakat tersebut. Penyataan tersebut diperkuat oleh ke 1 sebagai berikut:

"masyarakatnya menjadi memiliki taraf hidup yang lebih baik dengan cara si masyarakat memanfaatkan dan merawat apa yang sudah dikasih oleh Jasa Marga. Selain itu juga bersinergi dengan BUMN karya lainnya yaitu Hutama Karya membuat saung belajar untuk anak-anak Paud usia dini."

Pada konsep Planet dalam Triple Bottom Line, perusahaan harus peduli terhadap lingkungan hidup dan keberlanjutan lingkungan dan keragaman hayati. Beberapa program kegiatan TJSP PT Jasa Marga (Persero) Tbk. yang berpijak pada prinsip ini biasanya berupa penghijauan lingkungan hidup, penyediaan sarana air bersih, perbaikan permukiman, pengembangan pariwisata (ekoturisme). Konsep 3P memiliki sistem kerja yang dapat bermanfaat bagi bagian tertentu dan dapat membantu pembangunan Negara tanpa mementingkan keuntungan perusahaan.

Untuk konsep planet pelestarian alam dilakukan perbaikan ekosistem sungai yang semula gersang dan tidak terawat, sekarang sudah ditanami tanaman menjadi lebih subur dan sungai juga terlihat lebih terlihat asri dan merawat tanaman produksi yang bisa dijual sehingga menjadikan profit seperti yang dikatakan key informan:

"Pelestarian lingkungan alam harus terjaga, yang tadinya di pinggiran sungai gersang dan tidak terawat, sekarang sudah ditanami tanaman menjadi lebih subur dan sungai 
juga terlihat lebih terlihat asri karena tanaman tadi, trus juga ada tanaman produksi yaitu buah-buahan kan bisa dijual sehingga menghasilkan taraf hidup masyarakat yang lebih baik nah itu bisa dijadikan profit untuk masyarakat sekitar."

Hal senada juga dikatakan oleh informan 1 yang mengatakan bahwa Sungai Cisadane merupakan sumber air utama di kota Tangerang maka dari itu masyarakat harus bisa merawat sungai agar bisa menikmati air yang bersih, seperti pernyataan berikut:

"cara merawat alamnya agar terlihat lebih bersih dari sebelumnya, sampah-sampah yang banyak dibantaran sungai dirawat dan dibersihkan agar Sungai Cisadane ini bisa dinikmati juga oleh masyarakat sekitar. Karena kan Sungai Cisadane juga merupakan sumber air utama di kota tangerang maka dari itu masyarakat sekitar harus merawat sungai agar bisa menikmati air yang bersih."

Pada konsep profit, Perusahaan berorientasi dalam keberlangsungan keuntungan ekonomi yang memungkinkan untuk terus beroperasi, berkembang, meningkatkan produktivitas, dan melakukan efisiensi biaya sehingga perusahaan mempunyai keunggulan. Dalam hal ini secara tidak langsung PT Jasa Marga (Persero) Tbk akan mendapatkan dukungan dari masyarakat khususnya masyarakat sekitar Sungai Cisadane. Pada Program Banksasuci masyarakat bisa memanfaatkan hasil dari buah-buahan yang mereka tanam dan hasilnya bisa mereka jual untuk kebutuhan sehari-hari, bukan hanya itu saja bank sampah Sungai Cisadane atau yang sering disebut Banksasuci itu kan artinya mengumpulkan sampahsampah bekas botol air minum mineral yang akan di pilah dan didaur ulang oleh mereka, terus dari situ mereka menampung dan dijual lagi ke penadah sampai sekarang. Seperti pernyataan key informan sebagai berikut:

"Nah untuk konsep profitnya, bagi perusahaan mendapat keuntungan dukungan masyarakat, bagi masyarakat, misalnya selain buah-buahan yang bisa dijual sehingga menghasilkan untuk mereka agar taraf hidup masyarakat yang lebih baik mba salah satunya juga karna ada project sampah plastik yang bisa dimanfaatkan dan didaur ulang oleh masyarakat sekitar untuk dikumpulkan dan dipilah, karena kan yang mau masuk ke kawasan Banksasuci ini juga diharuskan membawa 1 botol plastik minimal untuk mengurangi populasi plastik dari situ sebenarnya banyak aspek positif yang didapat dari sana gituloh. Banksasuci kan intinya itu bank sampah sungai Cisadane jadi itu kan mengumpulkan sampah-sampah bekas botol air minum mineral yang akan di pilah dan didaur ulang oleh mereka, terus dari situ mereka menampung dan dijual lagi ke penadah sampai sekarang."

Pada saat observasi lapangan, peneliti melihat kumpulan botol plastik bekas pakai yang wajib dibawa saat memasuki kawasan Banksasuci agar masyarakat perduli terhadap lingkungan dan mengurangi sampah plastik. Bukan hanya itu saja botol plastik tersebut akan dikumpulkan dan dipilah lalu dijual ke penadah sekitar Banksasuci. Informan pertama menyatakan masyarakat bisa mendapat manfaat dari buah-buahan yang sudah diberikan dan dapat dimanfaatkan. Selain itu juga ada projek sampah yang bisa dimanfaatkan dan didaur ulang, seperti pernyataan berikut:

"Profit didapatkan perusahan berupa dukungan masyarakat. Untuk masyarakat bisa dimanfaatkan dari bibit buah-buahan yang sudah diberikan nah dari situkan dimanfaatkan hasilnya untuk kebutuhan masyarakat sehari-hari, karena banyak juga masyarakat yang tidak memiliki pekerjaan maka mereka bisa mengisi kesehariannya dengan merawat dan melestarikan tanaman yang ada hingga membuahkan hasil. Selain itu masyarakat bisa memanfaatkan projek sampah yang bisa dimanfaatkan dan didaur ulang oleh masyarakat sekitar untuk dikumpulkan dan dipilah lalu hasilnya dijual ke penadah hingga sekarang." 
Sebagai gambaran atas hasil bantuan yang diberikan kepada masyarakat Cisadane adalah sebagai berikut:

Tabel 1 Hasil Bantuan PT Jasa Marga (Persero) Tbk

\begin{tabular}{|c|c|c|c|}
\hline Bentuk bantuan & Sasaran & $\begin{array}{l}\text { Perbaikan } \\
\text { lingkungan }\end{array}$ & Keuntungan \\
\hline $\begin{array}{l}\text { Bibit tanaman buah } \\
\text { dan jenis tanaman } \\
\text { bunga }\end{array}$ & $\begin{array}{l}\text { Masyarakat dibina } \\
\text { untuk merawat bibit } \\
\text { tanaman yang sudah } \\
\text { diberikan }\end{array}$ & $\begin{array}{l}\text { Tempat berbagai } \\
\text { pohon ditanam dan } \\
\text { dikembangbiakkan }\end{array}$ & $\begin{array}{l}\text { Pendapatan } \\
\text { masyarakat } \\
\text { meingkat dari hasil } \\
\text { tanaman produksi }\end{array}$ \\
\hline Flying Fox & $\begin{array}{l}\text { Masyarakat yang } \\
\text { berminat olah raga }\end{array}$ & $\begin{array}{ll}\text { Tanah } & \text { kosong } \\
\text { terpelihara } & \text { karena } \\
\text { dimanfaatkan untuk } \\
\text { sarana Flying Fox }\end{array}$ & $\begin{array}{l}\text { Menjalin } \\
\text { kebersamaan } \\
\text { keluarga, sahabat } \\
\text { dan komunitas }\end{array}$ \\
\hline Wall Climbing & $\begin{array}{l}\text { Masyarakat yang } \\
\text { berminat olah raga } \\
\text { murah di bantaran } \\
\text { sungai yang asri }\end{array}$ & $\begin{array}{ll}\text { Tanah } & \text { kosong } \\
\text { terpelihara karena } \\
\text { dimanfaatkan untuk } \\
\text { sarana Wall } & \text { Climbing }\end{array}$ & $\begin{array}{l}\text { Menjalin } \\
\text { kebersamaan } \\
\text { keluarga, sahabat } \\
\text { dan komunitas } \\
\text { Cisadane }\end{array}$ \\
\hline Saung belajar & $\begin{array}{l}\text { Anak anak } \\
\text { mendapatkan } \\
\text { pendidikan usia dini } \\
\text { dengan didirikannya } \\
\text { PAUD }\end{array}$ & $\begin{array}{lr}\text { Mendapatkan } & \\
\text { pendidikan } & \text { yang } \\
\text { layak } & \text { bagi } \\
\text { masyarakat } & \text { kurang } \\
\text { mampu } & \end{array}$ & $\begin{array}{l}\text { Anak-anak } \\
\text { mendapatkan saana } \\
\text { untuk belajar dan } \\
\text { mencari infomasi }\end{array}$ \\
\hline Saung Pertemuan & $\begin{array}{l}\text { Masyarakat yang } \\
\text { ingin } \\
\text { bermusyawarah, } \\
\text { arisan dan family } \\
\text { gathering }\end{array}$ & $\begin{array}{lr}\text { Menjadi } & \text { tempat } \\
\text { berkumpul } & \text { yang } \\
\text { murah, dengan } & \text { alam } \\
\text { yang asri } & \end{array}$ & $\begin{array}{l}\text { Sebagai } \\
\text { pertemuan } \\
\text { formal } \\
\text { informal }\end{array}$ \\
\hline
\end{tabular}

\section{Sumber: Hasil Olahan Penulis}

Dengan demikian PT Jasa Marga (Persero) Tbk melalui kegiatan Program Banksasuci ini bertanggung jawab pada kepentingan keberlanjutan pertumbuhan perusahaan dan Tanggung Jawab pada lingkungan yang saling melengkapi. Aktivitas menjalin komunikasi harus berjalan dengan baik dengan komunitas sekitar salah satunya dengan masyarakat sekitar Sungai Cisadane ini sehingga perhatian PT Jasa Marga (Persero) Tbk tidak hanya terimplementasi pada keuntungan bisnis semata namun juga peduli terhadap aktivitas pengelolaan lingkungan dan penjagaan hubungan yang baik dengan stakeholders di dalamnya. Dengan selalu melakukan manajemen komunikasi yang baik maka aktivitas komunikasi dapat berjalan baik sehingga terjalin hubungan yang baik dalam bentuk kerjasama kedua belah pihak yang saling menguntungkan.

\section{SIMPULAN}

Simpulan dalam penelitian ini adalah manajemen komunikasi dalam wujud tanggung jawab sosial perusahaan PT Jasa Marga (Persero) Tbk melalui penyaluran bantuan pada Program Banksasuci dilakukan melalui tahapanan antara lain tahapan komunikasi melalui tahap perencanaan komunikasi, tahap pelaksanaan dan tahap evaluasi komunikasi melalui monitoring. Pada tahap perencanaan komunikasi berisi identifikasi masalah dengan mengomunikasikan perencanaan dan persiapan program penyaluran bantuan ke Banksasuci. Peran komunikator yaitu dilaksanakan oleh bagian Corporate Development PT Jasa Marga (Persero) Tbk. Pada tahap persiapan komunikasi terdiri dari kegiatan sosialisasi, proses survei dan penilaian hasil survei. Tahap pelaksanaan komunikasi dilakukan dengan kegiatan 
penandatanganan perjanjian kerjasama dan penyerahan bantuan secara simbolis, kegiatan pembinaan yang terdiri dari pembinaan masyarakat, dan pendampingan. Pada tahap monitoring dan evaluasi terdiri dari kegiatan monitoring yang meliputi reminding call, melalui media komunikasi Whatshapp group secara informal, serta kunjungan lapangan serta kegiatan evaluasi. Melalui manajemen komunikasi yang baik maka komunikasi berlangsung lancar dan saling menguntungkan. Keseluruhan kegiatan tanggung jawab sosial perusahaan PT Jasa Marga (Persero) Tbk. mengedepankan 3 (tiga) prinsip yaitu Triple Bottom Line, yaitu people, planet dan profit. Dengan demikian PT Jasa Marga (Persero) Tbk. bertanggung jawab pada kepentingan keberlanjutan pertumbuhan perusahaan dan juga tanggung jawab pada lingkungan.

\section{DAFTAR PUSTAKA}

Abidin, Z. (2015). Manajemen Komunikasi Filosofi Konsep Dan Aplikasi. Bandung: Pustaka Setia.

Mulyana, D. (2010). Metodologi Penelitian Kualitatif. Bandung: Remaja Rosdakarya.

Lestari, P., Prabowo, A., \& Wibawa, D. A. (2012). Manajemen Komunikasi Bencana Merapi 2010 pada saat Tanggap Darurat. Jurnal Ilmu Komunikasi, 10, 173-197. Retrieved from http://bencana.bappenas.go.id/imdff/renaksi-

Michael, R., Raharjo, S. T., \& Resnawaty, R. (2019). Program Csr Yayasan Unilever Indonesia Berdasarkan Teori Triple Bottom Line. Focus : Jurnal Pekerjaan Sosial. https://doi.org/10.24198/focus.v2i1.23116

Muhtar, S. M., Cangara, H., \& Unde, A. A. (2013). Strategi Komunikasi Dalam Pelaksanaan Program Corporate Social Responsibility ( Csr ) Oleh Humas Pt. Semen Tonasa Terhadap Komunitas Lokal Di Kabupaten Pangkajene Dan Kepulauan. Communication Strategy on Corporate Social Responsibility ( CSR ) Implementat. 2(1), 90-99.

Mursitama, T. N., Noerlina, \& Wulandari, N. B. (2019). The study of corporate social responsibility in emerging economies: The case of SME's, tourism, environment upgrade programs in Indonesia. International Journal of Scientific and Technology Research, 8(6), 22-24.

Suwarso, W. A. (2020). Strategi Komunikasi Pemasaran Sosial Oleh Organisasi. 1-11.

Widjaja, G., \& Pratama, Y. . (2018). Corporate Social Responsibility: The WBCD"s journey, dalam Risiko Hukum \& Bisnis Perusahaan Tanpa CSR. Jakarta: Forum Sahaba.

Yulaika, R. (2019). Strategi Pengelolaan Komunikasi Corporate Social Responsibility (CSR) Pt Perkebunan Nusantara V Melalui Program Kemitraan Dalam Pemberdayaan UMKM Di Kabupaten Kampar. JOM FISIP., 6(2), 1-14.

Yusuf, B., \& Ridwan, H. (2018). Manajemen Komunikasi Dalam Pengelolaan Informasi Pembangunan Daerah (Pada Biro Humas Dan PDE Sekretariat Daerah Propinsi Sulawesi Tenggara). Jurnal Komunikasi Hasil Pemikiran Dan Penelitian: 50-64 